\title{
Soil Quality Indicators After Sequential Applications of Poultry Litter
}

\author{
Jackeline Vieira do Santos Laroca ${ }^{1}$, Tatiane Andrea de Camargo ${ }^{1}$, Camila Menezes Rodrigues da Silva ${ }^{1}$, \\ Juliana Mendes Andrade de Souza ${ }^{1}$, Andressa Selestina Dalla Côrt São Miguel ${ }^{2}$, Diego Oliveira Ribeiro ${ }^{3}$, \\ Rafael Gonçalves Cuissi ${ }^{1}$, Leandro Pereira Pacheco ${ }^{1}$, Francine Damian da Silva ${ }^{1} \&$ Edicarlos Damacena de Souza ${ }^{1}$ \\ ${ }^{1}$ Universidade Federal de Mato Grosso, Rondonópolis, Mato Grosso, Brazil \\ ${ }^{2}$ Universidade Estadual Paulista, Botucatu, São Paulo, Brazil \\ ${ }^{3}$ UNIFIMES-Centro Universitário de Mineiros, Goiás, Brazil \\ Correspondence: Jackeline Vieira dos Santos Laroca, Universidade Federal de Mato Grosso, Rodovia \\ Rondonópolis, Guiratinga, KM 06, MT 270, CEP 78735-901, Rondonópolis, Mato Grosso. Tel: \\ 55-669-9657-2399. E-mail: jacke.laroca@gmail.com
}

Received: June 30, 2018

doi:10.5539/jas.v11n3p590
Accepted: December 2, 2018 Online Published: February 15, 2019

URL: https://doi.org/10.5539/jas.v11n3p590

\begin{abstract}
Application of poultry litter may lead to major changes in the structural and functional properties of soil. Understanding these alterations is crucial for assessing the effect of organic wastes on the soil quality and attributes. The purpose of this study was to assess the influence of use of poultry litter on increased organic matter, microbiological activity and physicochemical properties of soils in the Brazilian Cerrado and identify a group of expressive indicators of changes for the assessed attributes. The research was conducted in Fazenda Alvorada, a farm located in Portelândia/GO (Brazil), consisting of the following accumulated doses of turkey litter: T0 (without application); T1 (26.32 $\left.\mathrm{Mg} \mathrm{ha}^{-1}\right)$; T2 (43.15 $\left.\mathrm{Mg} \mathrm{ha}^{-1}\right)$; T3 (57.6 Mg ha $\left.{ }^{-1}\right)$. The experimental design consisted of randomized blocks and four replications. Sequential applications of poultry litter provide increases in the variables related to organic matter, mainly in particulate nitrogen and total nitrogen stocks. Applications of lower doses resulted in increases of microbial biomass carbon and microbial quotient. Concerning soil physicochemical properties, available phosphorus, the sum of bases and base saturation were the variables that exhibited the most significant changes with increased doses of poultry litter. The metabolic quotient was the most expressive indicator to represent soil alterations resulting from application of poultry litter.
\end{abstract}

Keywords: soils, organic fertilization, microbial biomass, organic matter and quality assessment

\section{Introduction}

The poultry industry has grown significantly over the world and the large amounts of wastes produced by this activity have become an environmental concern since their improper disposal may contaminate soils and waters (Kominko et al., 2017). Thus, the use of these organic compounds in farming has been a prospective option because it is not just a sustainable model for utilization of wastes but it also favors optimal nutrients cycling (Komiyama, Kobayashi, \& Yahagi, 2012), thus reducing the amounts of chemical fertilizers and corresponding costs (Tewolde \& Sistani, 2014).

Production systems that promote the incorporation of organic residues, either from plants or animals into the soil, contribute to increase the stocks of organic matter (OM) in the soil (Endale et al., 2010), enhance microbial activity (Ashworth et al., 2017), reduce soil losses caused by erosion, thus contributing to an improvement of soil physicochemical attributes (Mosaddeghi et al., 2009). In this regard, studies report the effective application of poultry litter to increase macronutrient contents in soil (Daronch et al., 2017) and stocks of organic matter (Adeli et al., 2009), enhance the microbiological activity and the $\mathrm{pH}$ of the solution in the soil (Pinto et al., 2012), as well as to improve water retention and infiltration in soil (Veum et al., 2014).

In this context, it is necessary to identify parameters to efficiently indicate the soil quality and demonstrate effective alterations that occur in the soil due to the use of organic wastes from animal sources and definition of technical criteria for correct dosage of this fertilizer in cropping (Pulido et al., 2017). However, it is very difficult to estimate an indicator of soil quality, because it can vary according to the type of soil and soil management, the climate and other specificities of each region. 
An indicator of soil quality, as far as possible, must be of easy determination or execution (Oberholzer et al., 2012), integrate biological, physical and chemical soil attributes and respective processes (Doran \& Parkin, 1994), and be cost-effective and easy to obtain. Thus, to achieve satisfactory results, it is necessary an evaluation of a set of indicators and their interrelations, i.e., to analyze the influence of indicators over others and their effects on alterations of different soil attributes.

So, the multivariate analysis appears as a tool capable of identifying how much an indicator of soil quality can influence another one, allowing the identification of a group of indicators that could contribute most to the changes occurred in soil (Nosrati et al., 2013). In addition, multivariate statistics makes it possible to study a great number of variables, grouping them according to their similarity, and selecting from pre-selected groups the ones with the highest discriminating power (Zuber et al., 2017).

In this context, it is believed that application of larger doses of litter of poultry, will contribute to the increase of organic matter and microbial biomass by the incorporation of nutrients, especially of $\mathrm{N}$, influencing directly in the physicochemical properties, mainly $\mathrm{pH}$ and base saturation.

In this regard, the aim of this study was to evaluate the influence of use of poultry litter on (i) organic matter increase, (ii) the microbiological activity and (iii) physicochemical properties of the Brazilian Cerrado soil. Based on these results, to identify (iv) which would be the best regulators of change of the assessed attributes, and (v) the best indicators of soil quality.

\section{Material and Methods}

\subsection{Study Areas}

The study was conducted in the Fazenda Alvorada, a farm located in the municipality of Portelândia/GO (Brazil) in a dystrophic Red Latosol (739 $\mathrm{g} \mathrm{kg}^{-1}$ of clay, $125 \mathrm{~g} \mathrm{~kg}^{-1}$ of silt and $136 \mathrm{~g} \mathrm{~kg}^{-1}$ of sand, in layer $0-20 \mathrm{~cm}$ depth) (Embrapa, 2006). Typical climate in the region is Aw (predominantly warm and semi-wet, with rainy summer and dry winter), according to Köppen classification, with mean rainfall of $1700 \mathrm{~mm}$ and mean temperature of $24.2^{\circ} \mathrm{C}$

The area where the experience was conducted is made up of 16 parcels of 0.5 ha each, totaling 8 ha of experimental area, grown with Urochloa decumbens in rotational grazing (two days of grazing and 30 days of rest). The stocking rate in the rainy seasons (October to May) is 20-25 female cattle (Girolando breed) with average live weight of $590 \mathrm{~kg}$. In the dry season (June to September) in addition to overnight grazing, the animals are fed corn silage during the day.

The pasture was introduced in 1995. The experiment was implemented in October 2008 with the application of the firsts doses of poultry litter. There was no kind of correction of acidity and chemical fertilization of the soil prior to and during the experiment. The waste used as organic fertilizer came from excreta of turkey farming on wood-based bedding, with the following composition (seven years of application on average: C-organic $=308 \mathrm{~g}$ $\mathrm{Kg}^{-1} ; \mathrm{N}=3.3 \% ; \mathrm{P}_{2} \mathrm{O}_{5}=3.6 \% ; \mathrm{K}_{2} \mathrm{O}=2.4 \% ; \mathrm{Ca}=4.2 \% ; \mathrm{Mg}=1.0 \% ; \mathrm{C} / \mathrm{N}$ ratio $=10 / 1 ;$ dry matter $=73.8 \% ; \mathrm{pH}$ in water $=7.8$.

\subsection{Experimental Design}

The experiment consisted of the following doses of accumulated turkey litter applied from 2008 to 2014: T0 (without application); T1 (26.32 $\left.\mathrm{Mg} \mathrm{ha}^{-1}\right)$; T2 (43.15 $\left.\mathrm{Mg} \mathrm{ha}^{-1}\right)$; T3 (57.6 $\mathrm{Mg} \mathrm{ha}^{-1}$ ).

The experimental design consisted of randomized blocks with four replications, each parcel represented by a paddock. Application of the waste was parceled out annually through broadcast applications at the beginning of each rainy season, using a lime spreader. After applications, the pasture land rested for 45 days and, afterwards, the animals entered for grazing.

\subsection{Soil Collection and Assessments}

Soil samples were collected in October 2015, in the layer 0.0-0.10 m deep, with the aid of a soil auger. Five simple samples were collected at random points of each parcel. Afterwards, the samples were put into plastic bags, identified and taken for laboratory analysis. The samples that were used for determination of biochemical attributes were kept under refrigeration until completion of the assessments, and the samples for analyses of chemical attributes were air dried, sieved in $2 \mathrm{~mm}$ mesh and stored in a dry place.

The total organic carbon (TOC) contents were determined by oxidation in dichromate solution, while total nitrogen (TN) contents were obtained by micro-Kjeldahl distillation, following the method proposed by Tedesco et al. (1995). Physical fractionation of the organic matter was carried out according to Cambardella \& Elliot (1992), where $20 \mathrm{~g}$ of soil and $80 \mathrm{Ml}$ of a sodium hexametaphosphate solution $\left(7.0 \mathrm{~g} \mathrm{~L}^{-1}\right)$ were stirred during 16 
hours in a horizontal stirrer, and then the suspension passed through a $53 \mu \mathrm{m}$ sieve with the aid of water jets. The material trapped in the sieve, consisting of particulate organic matter (POM), was oven dried at $65^{\circ} \mathrm{C}$ to constant weight, had its mass quantified, was crushed in porcelain-grade crusher and had the $\mathrm{C}$ and $\mathrm{N}$ contents determined (Tedesco et al., 1995).

The stocks of TOC (S-TOC), particulate organic carbon (S-POC), total nitrogen (S-NT) and nitrogen in the particulate organic matter (S-NPOM) were calculated by the equivalent soil mass method so that the soil mass in the treatments was defined based on the lower soil mass value taken as reference (Ellert \& Bettany, 1995); thus, the stocks calculation was based on bulk densities of $0.87 \mathrm{~kg} \mathrm{dm}^{-3}$ for the $0-10 \mathrm{~cm}$ layer.

For analysis of the soil microbial activity, microbial biomass carbon (MBC) (Vance et al., 1987) and microbial biomass nitrogen $(\mathrm{MBN})$ (Brookes, 1995) were determined. The soil basal respiration was assessed by quantifying the $\mathrm{CO}_{2}$ released during soil incubation, where $\mathrm{CO}_{2}$ was captured in a $\mathrm{NaOH} 0.05 \mathrm{~mol} \mathrm{~L}^{-1}$ solution and then titrated with $\mathrm{HCl}$ (Alef \& Nanninpieri, 1995). The metabolic quotient $\left(q \mathrm{CO}_{2}\right)$ was obtained by the basal respiration-to-MBC ratio (Anderson \& Domsh, 1993) and the microbial quotient ( $q$ MIC) by the MBC-to-TOC ratio (Sparling \& West, 1988).

Chemical analyses of soil that were carried out were: $\mathrm{pH}$, available phosphorus and exchangeable bases $(\mathrm{Ca}, \mathrm{Mg}$ and K) following the method proposed by Embrapa (1997). Based on the results of the chemical analyses, sum of bases (SB), cation exchange capacity (CEC) and base saturations (V\%) were calculated.

To assess soil aggregation, samples of undeformed soil blocks measuring $0.15 \mathrm{~m} \times 0.10 \mathrm{~m} \times 0.10 \mathrm{~m}$ were collected. Subsequently, the samples were wrapped in PVC film (Polyvinyl chloride) to maintain the stability of the structure and placed in plastic bags, identified and packed in carton boxes for transportation. In the laboratory, after removing the PVC film, the samples were moistened and declodded at their weakness points and arranged for air drying. For the study of wet aggregates, the methodology was adapted from Silva \& Mielniczuk (1997) and, subsequently, the weighted average diameter of the aggregates was calculated.

\subsection{Statistical Analysis of Data}

For the statistical analyses, data were grouped into three main groups: organic matter (OM) microbiological activity (MA) and physicochemical attributes (PC) of the soil. In the OM group, were included S-TOC, S-TN, $\mathrm{S}-\mathrm{POC}, \mathrm{S}-\mathrm{NPOM}$ and total $\mathrm{C} / \mathrm{N}$ ratio. In the MA group, were included $\mathrm{MBC}, \mathrm{MBN}, \mathrm{BR}, q \mathrm{CO}_{2}$ and $q \mathrm{MIC}$. In the PC group, were included SB, phosphorus, $\mathrm{CEC}, \mathrm{V} \%, \mathrm{pH}$ and the weighted average diameter of the aggregates.

For each dataset, principal components analysis (PCA) was carried out aiming to reduce/eliminate overlapping and choose the most representative form of data based on linear combinations of the original variables (Pare et al., 2005). Next, an analysis of similarity (ANOSIM) was conducted to evaluate the difference between the poultry litter doses applied to the soil. Afterwards, multivariate analyses in distance-based linear models (DistLM) were conducted aiming to identify which variables in each studied group best explained the changes of the other correlated groups. Based on these results, in each group, the variables that best explained the change of the correlated groups (eliminating overlaps) were selected, and then the same test (DistLM) was applied in order to verify which variables would be considered the best indicators of soil quality.

These analyses were carried out with the aid of Primer v6 and Permanova + software (Anderson, 2005). As pre-treatment of data, standardization was performed to standardize the units of variables. The tests were carried out using Bray-Curtis similarity index, suitable for environmental variable matrices.

\section{Results}

\subsection{Increase of Soil Organic Matter}

In the principal components analysis for the set of variables relating to soil organic matter, it can be seen that the Principal Component 1 (PC1), which explains $76.8 \%$ of the total data variation, is positively correlated with the increased doses of poultry litter and an increase of S-TOC, S-TN, S-POC and S-NPOM and negatively correlated with total $\mathrm{C} / \mathrm{N}$ ratio (Figure 1). These results show a well-defined graphical distribution of three groups, T0, T1 (26.32 $\left.\mathrm{Mg} \mathrm{ha}^{-1}\right)$ and T2+T3 (43.15 and 57.6 $\mathrm{Mg} \mathrm{ha}^{-1}$, respectively (Figure 1).

When comparing the treatments by the analysis of similarity (ANOSIM), it can be seen that only T2 and T3 were similar to each other $(\mathrm{P}=5.7 \%$; Table 1) as shown in the PCA itself (Figure 1). It can also be seen that the greatest dissimilarities occurred when the soils that did not receive doses of poultry litter (T0) were compared with the other treatments (highest statistic $\mathrm{R}$ values; Table 1). 


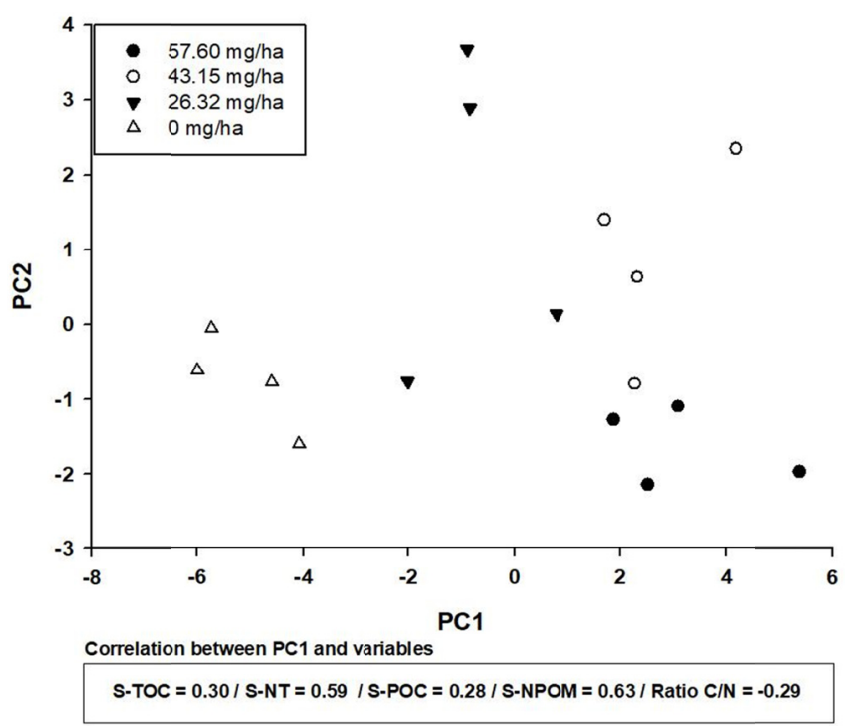

Figure 1. Principal components analysis (PCA) for the variables related to organic matter of a dystrophic Red Latosol subjected to different doses of poultry litter. S-TOC $=$ Stock of total organic carbon; S-TN $=$ Stock of total nitrogen; $\mathrm{S}-\mathrm{POC}=$ Stock of particulate organic carbon: S-NPOM $=$ Stock of nitrogen in particulate organic matter and $\mathrm{C} / \mathrm{N}$ ratio. $* \mathrm{PC} 1$ explains $76.8 \%$ and $\mathrm{PC} 2$ explains $18.4 \%$ of total variation

Table 1. Paired comparison by Analysis of Similarity (ANOSIM) for a Red Latosol subjected to different doses of poultry litter

\begin{tabular}{lll}
\hline ORGANIC MATTER & & \\
\hline Doses (ton/ha) & Statistical R & Significance level (\%)* $^{*}$ \\
\hline 0 vs. 26 & 0.969 & 2.9 \\
0 vs. 43 & 1.000 & 2.9 \\
0 vs. 58 & 1.000 & 2.9 \\
26 vs. 43 & 0.490 & 2.9 \\
26 vs. 58 & 0.740 & 2.9 \\
43 vs. 58 & 0.417 & 5.7 \\
\hline MICROBIAL ACTIVITY & & \\
\hline Groups (Doses) & Statistical R & Significance level (\%)* \\
\hline 0 vs. 26 & 1.00 & 2.9 \\
0 vs. 43 & 1.00 & 2.9 \\
0 vs. 58 & 1.00 & 2.9 \\
26 vs. 43 & 0.135 & 17.1 \\
26 vs. 58 & 0.854 & 2.9 \\
43 vs. 58 & 0.917 & 2.9 \\
\hline PHYSICOCHEMICAL PROPERTIES & & \\
\hline Groups (Doses) & Statistical R & Significance level (\%)* \\
\hline 0 vs. 26 & 0.958 & 2.9 \\
0 vs. 43 & 1.000 & 2.9 \\
0 vs. 58 & 1.000 & 2.9 \\
26 vs. 43 & 0.719 & 2.9 \\
26 vs. 58 & 0.938 & 2.9 \\
43 vs. 58 & 0.677 & 2.9 \\
\hline
\end{tabular}

Note. *The higher the $\mathrm{R}$ value the higher the dissimilarity.

The increased doses of poultry litter applied to soil promotes increases in the OM-related variables (Table 2), especially in S-NPOM and S-TN. On the other hand, the soil that did not receive poultry litter applications exhibits a $61.32 \%$ increase in the $\mathrm{C} / \mathrm{N}$ ratio when compared to the treatment that received the highest dose. 
Table 2. Mean and standard deviation of organic matter-related attributes of a Red Latosol subjected to doses of poultry litter

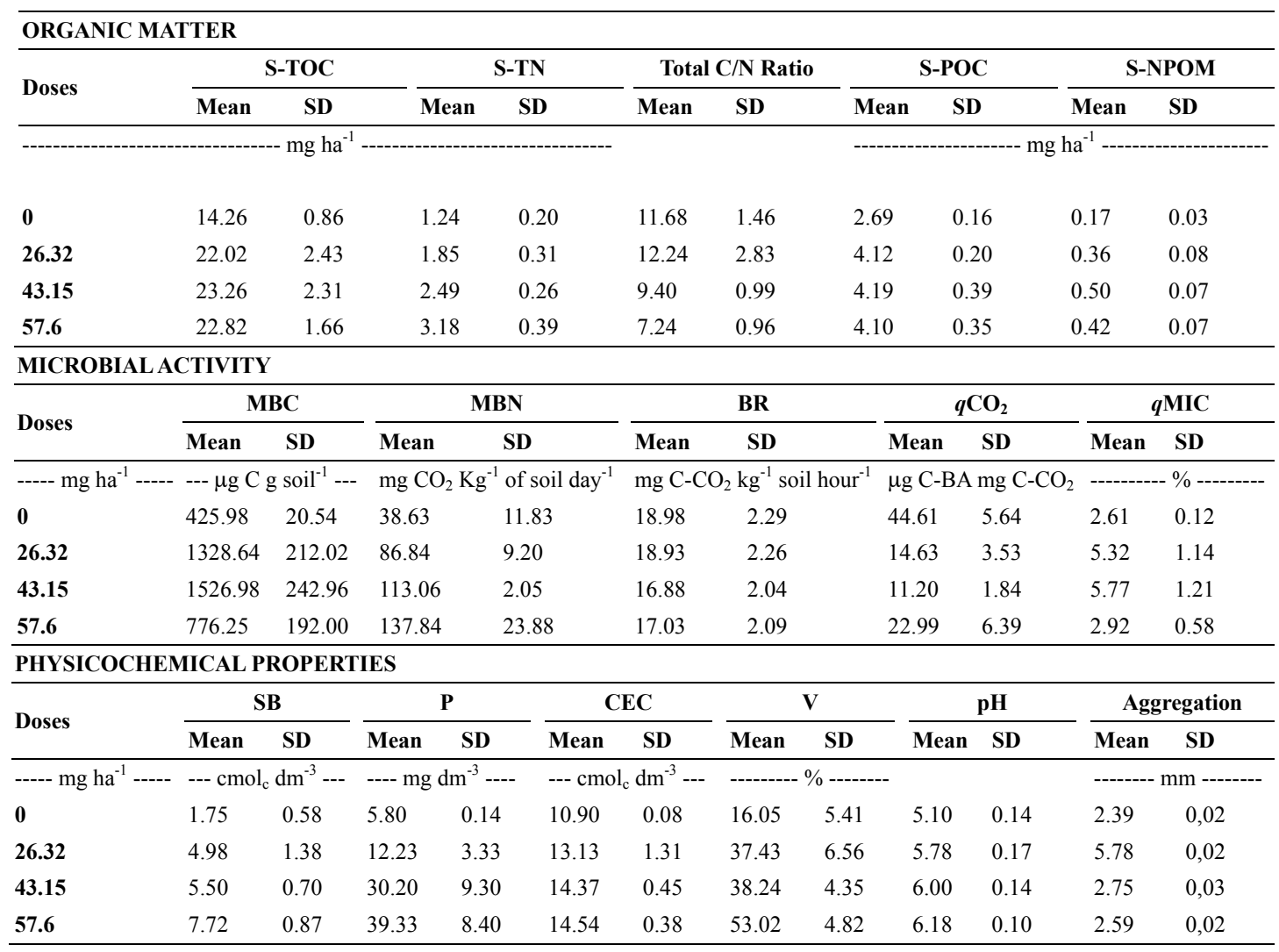

Note. S-TOC $=$ Stock of total organic carbon; S-NT $=$ Stock of total nitrogen; S-POC $=$ Stock of particulate organic carbon; $\mathrm{S}-\mathrm{NPOM}=$ Stock of nitrogen in particulate organic matter and $\mathrm{C} / \mathrm{N}$ ratio. $\mathrm{MBC}=$ Microbial biomass carbon; $\mathrm{MBN}=$ Microbial biomass nitrogen; $\mathrm{BR}=$ Basal respiration; $q \mathrm{CO}_{2}=$ Metabolic quotient; Qmic $=$ Microbial quotient; $\mathrm{SB}=$ Sum of bases; $\mathrm{P}=$ Phosphorus; $\mathrm{CEC}=$ Cation exchange capacity; $\mathrm{V}=\mathrm{Bases}$ saturation; $\mathrm{pH}=$ Potential of Hydrogen. SD: Standard Deviation.

According to the multivariate analysis using distance-based linear models (DistLM), it can be seen that among the microbial activity-related variables, $\mathrm{MBN}$ and $q \mathrm{CO}_{2}$ explained best the changes in soil organic matter (Table $3)$. Regarding the variables relating to physicochemical attributes, all of them explained the organic matter changes (Table 3). However, $\mathrm{pH}$ and bases saturation (V) indicated the highest explanation rates. The variable that explained less the organic matter changes was the weighted average diameter of aggregates. 
Table 3. Distance-based multivariate analysis for linear models (DistLM) for organic matter relating to microbial activity and physicochemical attributes variables of a Red Latosol subjected to poultry litter doses.

\begin{tabular}{llll}
\hline ORGANIC MATTER/MICROBIAL ACTIVITY & & \\
\hline Variables & Pseudo-F & P & Proportion (\%)* \\
\hline $\mathrm{MBC}$ & 5.420 & 0.022 & 27.91 \\
$\mathrm{MBN}$ & 62.015 & 0.001 & 81.58 \\
$\mathrm{BR}$ & 1.1234 & 0.332 & 7.42 \\
$q \mathrm{CO}_{2}$ & 13.820 & 0.004 & 49.67 \\
$q \mathrm{MIC}$ & 1.7823 & 0.196 & 11.29 \\
\hline ORGANIC MATTER/PYSICOCHEMICAL PROPERTIES & \\
\hline Variables & Pseudo-F & $\mathbf{P}$ & Proportion (\%)* \\
\hline SB & 27.638 & 0.001 & 66.38 \\
P & 22.363 & 0.001 & 61.50 \\
CEC & 25.735 & 0.001 & 64.77 \\
V & 28.035 & 0.001 & 66.69 \\
pH & 34.673 & 0.001 & 71.24 \\
Aggregation & 9.7302 & 0.003 & 41.00 \\
\hline
\end{tabular}

Note. * Percentage of how much it explains the microbial activity alterations in soil. $\mathrm{MBC}=$ Microbial biomass carbon; $\mathrm{MBN}=$ Microbial biomass nitrogen; $\mathrm{BR}=$ Basal respiration; $q \mathrm{CO}_{2}=$ Metabolic quotient; $\mathrm{qMIC}=$ Microbial quotient; $\mathrm{SB}=$ Sum of bases; $\mathrm{P}=$ Phosphorus; $\mathrm{CEC}=$ Cation exchange capacity; $\mathrm{V}=$ Base saturation; $\mathrm{pH}=$ Potential of Hydrogen.

\subsection{Soil Microbial Activity}

With respect to the soil microbial activity group, it can be seen three distinct groups formed by the dispersion in the PCA eigenvalues (Figure 2). The first group, with negative PC1 values (79.4\% explanatory power), corresponds to the treatment without application of poultry litter (T0) (Figure 2), being strongly related to the increased soil metabolic quotient $\left(q \mathrm{CO}_{2}\right)$ and basal respiration (BR), which exhibited a rise of $94.0 \%$ and $11.4 \%$, respectively, when compared to the treatment with the maximum dose (Table 2). Regarding the organic matter group, the main discrepancies between the pairs assessed by ANOSIM were observed when comparing the absence of application of poultry litter to all doses assessed (higher $R$ values, Table 1).

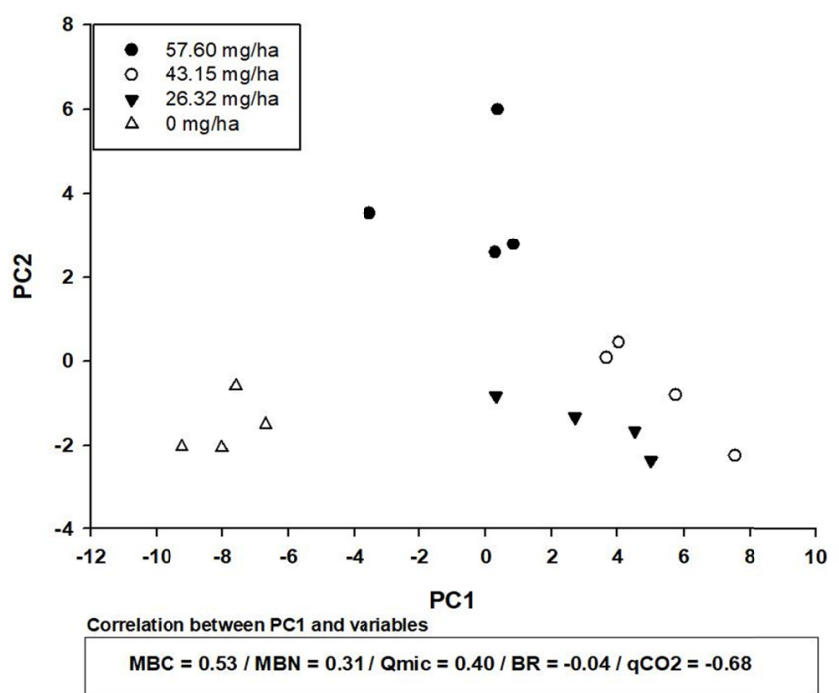

Figure 2. Principal components analysis (PCA) for five variables related to the microbiological activity of a Red Latosol subjected to different doses of poultry litter. $\mathrm{MBC}=$ Microbial biomass carbon; $\mathrm{MBN}=$ Microbial biomass nitrogen; $\mathrm{BR}=$ Basal respiration; $q \mathrm{CO}_{2}=$ Metabolic quotient; $\mathrm{Qmic}=$ Microbial quotient. * $\mathrm{PC1}$ explains $79.4 \%$ and PC2 $16.4 \%$ of total variation 
The second group, with predominant positive values in PC1 (Figure 2), is represented by the highest dose of poultry litter $\left(\mathrm{T} 3=57.6 \mathrm{Mg} \mathrm{ha}^{-1}\right)$, which provided an increase of $256.8 \%$ in MBN compared to the treatment without application of poultry litter (Table 2). The treatments with two intermediate dosages (T1 $=26.32 \mathrm{Mg} \mathrm{ha}^{-1}$ and $\left.\mathrm{T} 2=43.15 \mathrm{Mg} \mathrm{ha}^{-1}\right)$ are in the same group with totally positive values in PC1, promoting an increase in the microbial biomass carbon (MBC) and microbial quotient ( $q$ MIC) (Table 2). The similarity of these two doses is exhibited again via ANOSIM, indicating a significance level of $17.1 \%$ (Table 1).

In the DistLM analysis for microbial activity, S-POC and S-NPOM were the variables that exhibited the best explanatory power over the variables related to soil organic matter (Table 4), whereas for the physicochemical attributes, the cation exchange capacity and $\mathrm{pH}$ exhibited a better explanatory power over microbial activity changes (Table 4).

Table 4. Distance-based multivariate analysis for a linear model (DistLM) for the microbial activity in soil relating to the organic matter and physicochemical variables of a Red Latosol subjected to different doses of poultry litter

\begin{tabular}{llll}
\hline MICROBIAL ACTIVITY/ORGANIC MATTER & & \\
\hline Variables & Pseudo-F & P & Proportion (\%)* $^{*}$ \\
\hline S-TOC & 12.9430 & 0.002 & 48.04 \\
S-TN & 5.6323 & 0.029 & 28.69 \\
C/N ratio & 1.7877 & 0.198 & 11.32 \\
S-POC & 14.756 & 0.001 & 51.31 \\
S-NPOM & 13.1720 & 0.002 & 48.48 \\
\hline MICROBIAL ACTIVITY/PHYSICOCHEMICAL PROPERTIES & \\
\hline Variables & Pseudo-F & P & Proportion (\%)* \\
\hline SB & 6.5057 & 0.014 & 31.73 \\
P & 4.4224 & 0.039 & 24.00 \\
CEC & 13.3360 & 0.006 & 48.78 \\
V & 6.1971 & 0.008 & 30.68 \\
pH & 12.020 & 0.003 & 46.19 \\
Aggregation & 6.4129 & 0.018 & 31.41 \\
\hline
\end{tabular}

Note. * Percentage of how much it explains the changes in soil microbial activity. S-TOC $=$ Stock of total organic carbon; S-TN $=$ Stock of total nitrogen; S-POC = Stock of particulate organic carbon; S-NPOM = Stock of nitrogen in particulate organic matter; $\mathrm{SB}=$ Sum of bases; $\mathrm{P}=$ Phosphorus; $\mathrm{CEC}=$ Cation exchange capacity; $\mathrm{V}=$ Base saturation; $\mathrm{pH}=$ Potential of Hydrogen. $\mathrm{S}-\mathrm{TOC}=$ Stock of total organic carbon; $\mathrm{S}-\mathrm{TN}=$ Stock of total nitrogen; S-POC $=$ Stock of particulate organic carbon; S-NPOM $=$ Stock of nitrogen in particulate organic matter and $\mathrm{C} / \mathrm{N}$ ratio.

\subsection{Soil Physicochemical Attributes}

In the PCA of the physicochemical properties group, it can be seen that four distinct groups of eigenvalues are formed, and the treatment with no application of poultry litter (T0) appears on the upper right side of PC1 (Figure 3). On the other hand, it is very clear an evolution of the groups to the left of PC1 with increased doses of poultry litter, and the treatment with the maximum dose exhibits the highest increase of soil physicochemical attributes (Figure 3). 


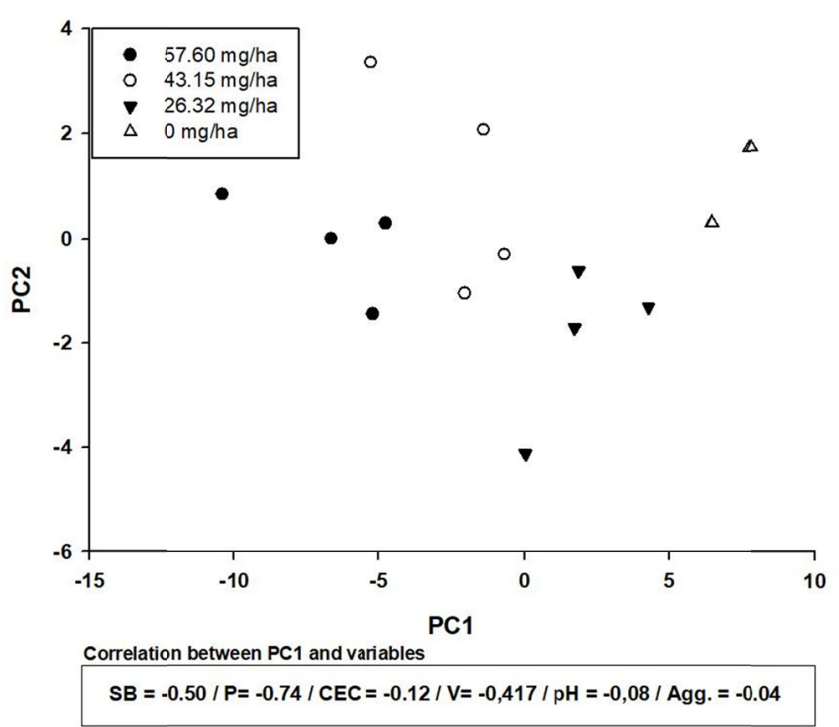

Figure 3. Principal components analysis (PCA) for six variables related to the physicochemical attributes of a Red Latosol subjected to different doses of poultry litter. $\mathrm{SB}=$ Sum of bases; $\mathrm{P}=$ Phosphorus; $\mathrm{CEC}=$ Cation exchange capacity; $\mathrm{V}=$ Bases saturation; $\mathrm{pH}=$ Potential of Hydrogen and Aggregation $=$ Soil aggregates stability. * PC1 explains $89.9 \%$ and $\mathrm{PC} 2$ explains $9.3 \%$ of total variation

In the analysis of similarity (ANOSIM), it can be seen that the treatments differ from one another (Table 1), as also indicated by the PCA (Figure 3), exhibiting a significance level of $2.9 \%$ for all pairs assessed. In addition, it can be seen a higher discrepancy for the pairs that have no application of poultry litter as reference, whereas for the higher doses $\left(\mathrm{T} 2=43.15 \mathrm{Mg} \mathrm{ha}^{-1}\right.$; $\left.\mathrm{T} 3=57.6 \mathrm{Mg} \mathrm{ha}^{-1}\right)$ they are the most similar. It can also be seen that the variables with increased poultry litter exhibited more levels of phosphorus (P), sum of bases (SB) and soil bases saturation $(\mathrm{V})$, of $578.1 \%, 341.1 \%$ and $230.3 \%$, respectively, for the highest dose, compared to the treatment with no application (Table 2).

As for DistLM, in the attributes related to the storage of soil organic matter, S-TN and S-POC were the variables that best explained the changes in soil physicochemical attributes (Table 5). For the microbial activity, MBN exhibited the greatest changes in physicochemical attributes followed by $q \mathrm{CO}_{2}$.

\subsection{Indicators of Change in the Overall Set of Soil Attributes}

The most expressive indicators regarding the explanatory rate, for the three groups of variables under analysis (OM, MA and PC), were $\mathrm{pH}, \mathrm{CEC}, \mathrm{V}, \mathrm{MBN}, \mathrm{S}-\mathrm{TN}, \mathrm{S}-\mathrm{NPOM}, q \mathrm{CO}_{2}$ and S-POC (Table 6).

In the multivariate analysis of the most significant indicators, using distance-based linear models (DistLM), it can be seen that $q \mathrm{CO}_{2}$ and S-POC are the attributes that best explain the changes in the overall set of variables studied. 
Table 5. Distance-based multivariate analysis for a linear model (DistLM) for physicochemical attributes related to microbial activity and organic material in a Red Latosol subjected to different doses of poultry litter

\begin{tabular}{llll}
\hline \multicolumn{1}{l}{ PHYSICOCHEMICAL PROPERTIES /MICROBIAL } & ACTIVITY & \\
\hline Variables & Pseudo-F & P & Proportion (\%)* \\
\hline $\mathrm{MBC}$ & 3.4483 & 0.075 & 19.76 \\
$\mathrm{MBN}$ & 61.525 & 0.001 & 81.46 \\
$\mathrm{BR}$ & 2.6491 & 0.133 & 15.91 \\
$q \mathrm{CO}_{2}$ & 10.913 & 0.001 & 43.03 \\
$\mathrm{Q}_{\text {mic }}$ & 1.1128 & 0.298 & 7.36 \\
\hline PHYSICOCHEMICAL PROPERTIES/ORGANIC MATTER & \\
\hline Variables & Pseudo-F & P & Proportion (\%)* \\
\hline S-TOC & 20.196 & 0.002 & 59.06 \\
S-TN & 42.919 & 0.001 & 75.40 \\
C/N ratio & 8.4866 & 0.005 & 37.74 \\
S-POC & 23.335 & 0.001 & 62.50 \\
S-NPOM & 18.753 & 0.002 & 57.25
\end{tabular}

Note. ${ }^{*}$ Percentage of how much it explains the changes in the soil physicochemical properties. MBC $=$ Microbial biomass carbon; $\mathrm{MBN}=$ Microbial biomass nitrogen; $\mathrm{BR}=$ Basal respiration; $q \mathrm{CO}_{2}=$ metabolic quotient; Qmic $=$ microbial quotient; $\mathrm{S}-\mathrm{TOC}=$ Stock of total organic carbon; $\mathrm{S}-\mathrm{TN}=$ Stock of total nitrogen; S-POC $=\mathrm{Stock}$ of particulate organic carbon; $\mathrm{S}-\mathrm{NPOM}=$ Stock of nitrogen in particulate organic matter and $\mathrm{C} / \mathrm{N}$ ratio.

Table 6. Distance-based multivariate analysis for a linear model (DistLM) for the most expressive group of indicators of a Red Latosol subjected to doses of poultry litter

\begin{tabular}{llll}
\hline Expressive Indicators & & & \\
\hline Variables & Pseudo-F & $\mathbf{P}$ & Proportion (\%)* \\
\hline $\mathrm{pH}$ & 4.09 & 0.05 & 22.61 \\
$\mathrm{CEC}$ & 3.85 & 0.05 & 21.56 \\
$\mathrm{~V}$ & 3.88 & 0.04 & 21.69 \\
$\mathrm{~S}-\mathrm{POC}$ & 4.77 & 0.03 & 25.40 \\
$\mathrm{~S}-\mathrm{TN}$ & 4.04 & 0.03 & 22.38 \\
$\mathrm{~S}-\mathrm{NPOM}$ & 4.14 & 0.03 & 22.83 \\
$\mathrm{MBN}$ & 4.31 & 0.03 & 23.53 \\
$q \mathrm{CO}_{2}$ & 13.68 & 0.00 & 49.43 \\
\hline
\end{tabular}

Note. $*$ Percentage of how much it explains the soil quality alterations. $\mathrm{pH}=$ Potential of Hydrogen; $\mathrm{CEC}=$ Cation exchange capacity; $\mathrm{V}=$ Bases saturation; $\mathrm{S}-\mathrm{POC}=$ Stock of particulate organic carbon; $\mathrm{S}-\mathrm{NPOM}=\mathrm{Stock}$ of nitrogen in the particulate organic matter; $\mathrm{S}-\mathrm{TN}=$ Stock of total nitrogen; $\mathrm{MBN}=$ Microbial biomass nitrogen; and $q \mathrm{CO}_{2}=$ Metabolic quotient.

\section{Discussion}

\subsection{Increase of Soil Organic Matter}

The PCA indicated that increased poultry litter doses applied to soil provided an increase of the soil organic matter (SOM), which can be seen in the formation of three distinct groups, showing a direct relation of the organic residue added to the soil with increased SOM. This is due to the mineralization of essential soil nutrients, which is controlled mainly by the organic matter and changes related to microbial activity, as described by Bünemann and Condron (2007), and by the amount, quality and frequency of organic residues added to soil and associated with the management system (Sá et al., 2013).

The group with the largest doses (T2 and T3) caused an increase in S-NPOM and S-TN, a result confirmed by ANOSIM, which favored microbial activity with consequent increase in the residues decomposition, since S-NPOM refers to more labile materials and S-TN refers to the total concentration of this nutrient in soil. Poultry litter incorporated to the soil two of the main components of SOM, carbon and nitrogen, and, as already mentioned, these essential nutrients are controlled by SOM and, consequently, by biomass microbial activity stimulation, making it more active (Dijkstra et al., 2013) and leading to increased stocks of SOM, as already reported by Franchini et al. (2007), and Boddey et al. (2010). 
On the other hand, the treatment without application of poultry litter resulted in a higher $\mathrm{C} / \mathrm{N}$ ratio compared to the other doses. This result is confirmed by ANOSIM, in which the greatest dissimilarities found when comparing $\mathrm{T} 0$ with the other applications of turkey litter reflected in soil $\mathrm{N}$ and $\mathrm{C}$ storage, resulting in large stocks of SOM. Thus, the high nitrogen contents found in the poultry litter, around 3.3\%, led to significant increases of total soil nitrogen, also found by Ge et al. (2010).

In the distance-based analysis for linear models (DistLM), with respect to the microbial activity variables, MBN and $q \mathrm{CO}_{2}$ were the attributes that contributed most to the changes in the stocks of SOM, for being related with an efficient use of $\mathrm{C}$. This is because higher $\mathrm{C}$ and $\mathrm{N}$ contents, added through poultry litter, tend to normalize the metabolic quotient as carbon is regulated by SOM and supplied as carbon dioxide (Howarth, 2007) by microbial respiration. Thus, additions of organic fertilizer, with high nitrogen contents, lead to a reduction of $\mathrm{CO}_{2}$ emission (Zang et al., 2017; Ge et al., 2010). Therefore, it was observed that the microbial biomass became more efficient, i.e. less $\mathrm{CO}_{2}$ is lost to the atmosphere and a higher rate of carbon is incorporated to the microbial biomass, resulting in lower $q \mathrm{CO}_{2}$ values (Cunha et al., 2011) and, consequently, storing more $\mathrm{C}$ amounts in soil.

The addition of organic fertilizer in the form of poultry litter led to increased SOM, directly influencing all physicochemical attributes, especially $\mathrm{pH}$ and bases saturation. SOM, when in decay, is the main source of negative charge (Pavinato \& Rosolem, 2008) in most soils, so it determines the soil's retention and bioavailability of cations and nutrients such as calcium, potassium, magnesium and ammonium. Therefore, a sequential addition of poultry litter increased $\mathrm{pH}$ and bases saturation, which are highly related, because as the $\mathrm{pH}$ value increases, the soil negative charges are free and may be filled by bases, rising the bases saturation of charges, due to the reduction of ions $\mathrm{H}$ in the solid phase of soil.

\subsection{Soil Microbial Activity}

The formation of three distinct groups in the PCA of the microbial activity group clearly confirms that the application of poultry litter provides variations in this group (Figure 2). No application of poultry litter favored $q \mathrm{CO}_{2}$ and BR increases (Table 2), indicating that the environment was under a condition of stress or disturbance, which resulted in greater $\mathrm{C}$ losses through the respiration process. Thus, the amount of $\mathrm{C}$ that could be stored in the OM was reduced; on the other hand, the addition of poultry litter resulted in higher $q \mathrm{MIC}$ levels, indicating a better conversion of poultry litter into SOM in the form of MBC (Aderson \& Domsch, 1978), which confirms the efficacy of $\mathrm{C}$ utilization by microbial biomass.

The addition of a larger dose of poultry litter $\left(\mathrm{T} 3=57.6 \mathrm{Mg} \mathrm{ha}^{-1}\right)$ provided MBN increases. This was due to the large amount of nitrogen contained in the composition of organic fertilizers from animal excreta (Daronch et al., 2017), which not only increased the soil storage but also benefitted the temporary immobilization by microbial biomass (Table 2), and a contributing immobilization to the reduction of losses by volatilization and leaching, since the nitrogen will later be released gradually through mineralization. In turn, with respect to $\mathrm{MBC}$ and $q \mathrm{MIC}$, there was a higher increase with the intermediate doses. In swine manure, higher dosages caused a decrease in the oxygen availability to the soil microbiota, resulting in a MBC reduction, as observed by Quadros et al. (2011).

However, in this study, it might have occurred stabilization of MBC due to the application of a high dose of poultry litter, causing a higher microbial activity. As a result, there is an increase of the mineralization rate and the nutrients cycling velocity without a corresponding immobilization of the nutrients by the microbial biomass, as reported by Andrade et al. (2016).

In the ANOSIM paired analysis, the largest dissimilarities found when comparing $\mathrm{T} 0$ with the other treatments confirm again that poultry litter applications may cause major changes in the structural and functional microbial populations. This is due to the potential of microorganisms to react rapidly to the introduction of substances with different physicochemical properties into their environment (Mierzwa-Hersztek et al., 2017). The analysis also showed that the intermediate doses (T1 and T2) did not indicatet significant differences, as shown in the PCA, and this is due to the stabilization of attributes such as $\mathrm{MBC}$ and $q \mathrm{MIC}$, which did not exhibit expressive alterations with doses over $26.32 \mathrm{Mg} \mathrm{ha}^{-1}$.

S-POC and S-NPOM are the attributes that best explained the variations in the microbial biomass group (Table 4), because they represent the labile fraction of SOM, i.e., the light fraction comprised of undecomposed plant residues and their products in partial decomposition (Cates \& Ruark, 2017) which consequently forms a storage of readily-available materials to microbial attack. Thus, these fractions of SOM are vitally important to maintaining the biochemical processes responsible for the microbial activity and also by interfering directly with the nutrients cycling, because the rapid mineralization of this labile material satisfies most of the plants' 
nutritional needs (Tomlinson et al., 2015). Thus, the rapid cycling of a small nutrients reserve may lead to a high level of fertility when compared to slow cycling of a large nutrients reserve.

Among the physicochemical attributes, CEC had the greatest influence on the microbial activity group. However, it must be emphasized that SOM, due to the great presence of electrical charges, will interfere directly on CEC, thus improving the availability of soil nutrients, moisture retention and structuring. As a result, all these factors will contribute to keeping microorganisms in soil. So, it can then be seen that a real interference with microbial activity occurs as a function of SOM. The $\mathrm{pH}$ also has a high relationship with the microbial activity, because changes in $\mathrm{pH}$ may favor or not soil microorganism communities. Novak et al. (2017) reported that increased pH values interfere with the availability of nutrients to the soil microorganisms as well as they also have an effect on selecting more efficient microbial populations for degradation of organic substrates.

\subsection{Soil Physicochemical Attributes}

Based on the PCA (Figure 3), it can be seen the formation of four distinct groups, which confirms the physicochemical attributes changes resulting from the application of different doses of poultry litter. For this reason, the paired comparison analysis showed a statistical difference between all doses (Table 1). It is still possible to observe that the group with the highest dose $\left(\mathrm{T} 3=57.6 \mathrm{Mg} \mathrm{ha}^{-1}\right)$ contributed to rise, especially, the available phosphorus, sum of bases and bases saturation in soil.

The $\mathrm{P}$ increase in the group that received the largest doses of poultry litter $\left(\mathrm{T} 3=57.6 \mathrm{Mg} \mathrm{ha}^{-1}\right)$ is linked to the constitution of such organic fertilizer, which has significant phosphorus concentrations. In addition, the increased $\mathrm{pH}$ value associated with SOM increases resulting from the greatest doses of poultry litter allows a greater availability of this nutrient ( $\mathrm{Li}$ et al., 2015). This effect is important from the point of view of $\mathrm{P}$ availability for grazing, since in this soil $\mathrm{P}$ fixation tends to be very high, making it difficult to increase the available contents of this element.

The increased base saturation is explained by the fact that the sum of bases consists of potassium, calcium and magnesium, and all these elements are present in the poultry litter, providing increased levels of these nutrients and, consequently, in the sum of bases and base saturation. Furthermore, decomposition of organic residues results in water-soluble compounds that form complexes with acid reactant cations in the soil solution, causing the release of anions that precipitate aluminum and, therefore, rise the base saturation (Petrere \& Anghinoni, 2001). Such increase not only contributes to the soil fertility but also influences the grass-growing potential, since the ideal level of base saturation, considering the upper layers, for the maximum production of nitrogen-fertilized Urochloa decumbens, is around 54\% (Oliveira et al., 2003).

The S-MB and S-TN considerably contributed to explain the physicochemical changes and this is due to the great amount of nitrogen inserted into the soil through the poultry litter. Such addition stimulates soil microorganisms, thus enhancing the transformation of organic residues into SOM. SOM is directly linked to improved physicochemical attributes (Sepat et al., 2014), mainly because it causes an increase of the CEC in soil (Silva \& Mendonça, 2007), rising the soil fertility. S-POC and $q \mathrm{CO}_{2}$ were also regulators of these properties. This fact may also be associated with the increase of SOM, since in more stable production systems, there may be microbial communities more efficient in incorporating the $\mathrm{C}$ available in the its biomass (Bhaduri et al., 2017), so it may exhibit a lower $q \mathrm{CO}_{2}$, resulting in larger amounts of $\mathrm{C}$ stored in soil.

\subsection{Indicators of Change of the Overall Soil Attributes}

Among the eight indicators assessed, $q \mathrm{CO}_{2}$ was the most expressive, while the others had similar contribution to represent soil alterations. This shows the importance of using biological indicators to assess soil quality, because the microbiota reveals a dynamic nature and high sensitivity to detect short-term changes in ecosystems in general (Brookes et al., 2013).

Therefore, the use of $q \mathrm{CO}_{2}$ is recommended for future studies on soil quality. However, it must be emphasized that the other indicators were equally important when compared with each other, thus demonstrating the need for studies addressing the multiplicity of physical, chemical and biological attributes, as in the present work, thus expressing the soil functioning as a whole and not just one attribute, taking into account that the term "soil quality" refers to the soil ability to perform all functions of nature (Doran, 1997).

\section{Conclusions}

(1) The increased organic matter in soil that resulted from the addition of poultry litter caused an increase of carbon and nitrogen stocks, especially when applied with intermediate doses, making $\mathrm{MBN}, q \mathrm{CO}_{2}, \mathrm{BS}$ and $\mathrm{pH}$ good SOM regulators. 
(2) The maximum doses of poultry litter produced an increase of MBN, whereas the intermediate doses increased MBC and $q \mathrm{MIC}$. The treatments without application of poultry litter exhibited microbiota stress with increased $\mathrm{BR}$ and $q \mathrm{CO}_{2}$. The attributes that explained most the variations of the microbial biomass group were S-POC and S-NPOM of the organic matter group and the CEC of the physicochemical properties group.

(3) All physicochemical attributes were enhanced by the maximum doses of application of poultry litter. The MBN and S-TN were the attributes that exhibited the highest explanation power for the physicochemical properties alterations.

(4) Among the group of indicators assessed, $q \mathrm{CO}_{2}$ exhibited a great potential for use in soil quality appraisals, showing the importance of biological indicators, which provide much faster responses to environmental changes.

(5) Multivariate analysis was effective in the analysis of the soil quality indicators by selecting the ones with the best explanations for the alterations occurred in soil.

\section{References}

Adeli, A., Sistani, K. R., Rowe, D. E., \& Tewolde, H. (2009). Effects of Broiler Litter Applied to No-Till and Tillage Cotton on Selected Soil Properties. Soil Science Society of American Journal, 71, 974-983. https://doi.org/10.2136/sssaj2006.0092

Aderson, J. P. E., \& Domsch, K. H. (1978). A physiological method for the quantitative measurement of microbial biomass in soils. Soil Biology and Biochemistry, 10, 215-221. https://doi.org/10.1016/0038-0717 (78)90099-8

Alef, K., \& Nannipieri, P. (1995). Methods in applied soil microbiology and biochemistry. London: Academic Press. https://doi.org/10.1016/B978-012513840-6/50024-0

Anderson, J. P. E., \& Domsch, K. H. (1993). The metabolic quotient $\left(q \mathrm{CO}_{2}\right)$ as specific activity parameter to assess the effects of environmental conditions, such as $\mathrm{pH}$, on the microbial biomass of forest soils. Soil Biology and Biochemistry, 25, 393-395. https://doi.org/10.1016/0038-0717(93)90140-7

Anderson, M. J. (2005). PERMANOVA: A FORTRAN computer program for permutational multivariate analysis of variance. Department of Statistics, University of Auckland, New Zealand.

Andrade, L. C., Andreazza, R., \& Camargo, F. A. O. (2016) Atividade microbiana em solos sob doses de lodo de estação de tratamento de efluentes de um aterro industrial. Ciência Rural, 46, 267-272. https://doi.org/ 10.159 0/0103-8478cr20140871

Ashworth, A. J., DeBruyn J. M., Allen, F. L., Radosevich, M., \& Owens, P.R. (2017). Microbial community structure is affected by cropping sequences and poultry litter under long-term no-tillage. Soil Biology and Biochemistry, 114, 210-219. https://doi.org/10.1016/j.soilbio.2017.07.019

Bhaduri, D., Purakayastha, T.J., Patra, A.K., Singh, M., \& Wilson, B. R. (2017). Biological indicators of soil quality in a long-term rice-wheat system on the Indo-Gangetic plain: Combined effect of tillage-water-nutrient management. Environmental Earth Sciences, 76, 1-14. https://doi.org/10.1007/s12665 $-017-6513-0$

Boddey, R. M., Jantalia, C. P., Conceição, P. C., Zanatta, J. A., Bayer, C., Mielniczuk, J., ... Urquiaga, S. (2010). Carbon accumulation at depth in Ferralsols under zero-till subtropical agriculture. Global Change Biology, 16, 784-795. https://doi.org/10.1111/j.1365-2486.2009.02020.x

Brookes, P. C. (1995). The use of microbial parameters in monitoring soil pollution by heavy metals. Biol Fert Soils, 19, 269-279. https://doi.org/10.1007/BF00336094

Brookes, P. C., Pietri, J.C.A., Wu, Y., \& Xu, J. (2013) Microbial Indicators of Soil Quality in Upland Soils. Molecular Environmental Soil Science, 1, 413-428. https://doi.org/10.1007/978-94-007-4177-5_14

Bünemann, E., \& Condron, L. (2007). Phosphorus and sulphur cycling in terrestrial ecosystems. In P. Marschner \& Z. Rengel (Eds.), Nutrient cycling in terrestrial ecosystems (pp. 65-92). Springer, Berlin, Germany. https://doi.org/10.1007/978-3-540-68027-7_3

Cambardella, C. A., \& Elliot, E. T. (1992). Particulate soil organic matter changes across a grassland cultivation sequence. Soil Science Society of America Journal, 56, 777-783. https://doi.org/10.2136/sssaj1992.036159 $95005600030017 \mathrm{x}$

Cardoso, E. J. B. N., \& Andreote, F. D. (2016). Microbiologia do solo [recurso eletrônico] (2nd ed.). Piracicaba: ESALQ. https://doi.org/10.11606/9788586481567 
Cates, A. M., \& Ruark, M. D. (2017). Soil aggregate and particulate C and N under corn rotations: responses to management and correlations with yield. Plant Soil, 415, 521-533. https://doi.org/10.1007/s11104-016-312 $1-9$

Cunha, E. D. Q., Stone, L. F., Ferreira, E. P. D. B., Didonet, A. D., Moreira, J. A. A., \& Leandro, W. M. (2011). Sistemas de preparo do solo e culturas de cobertura na produção orgânica de feijão e milho: II-atributos biológicos do solo. Revista Brasileira de Ciência do Solo, 35, 603-611. https://doi.org/10.1590/S010 0-06832011000200029

Daronch, A. G. C. C., Chiapetti, T. P., Rinaldi, L. K., Barbosa, J. A., Ritter, G., Rocha, M. E. L, ... Perego, I. (2017). Chemical Characterization of Soil with Superficial Application of Avian Bed in Succession to Canola Cultivation. Journal of Agricultural Science, 9, 220-225. https://doi.org/10.5539/jas.v9n10p220

Dijkstra, F. A., Carrillo, Y., Pendall, E., \& Morgan, J. A. (2013) Rhizosphere priming: A nutrient perspective. Front Microbiol, 4, 1-8. https://doi.org/10.3389/fmicb.2013.00216

Doran, J. W. (1997). Soil quality and sustainability. Congresso Brasileiro de Ciência do Solo, Sociedade Brasileira de Ciência do Solo.

Doran, J. W., \& Jones, A. J. (1996). Methods for assessing soil quality (p. 410). Science Society of America.

Ellert, B. H., \& Bettany, J. R. (1995). Calculation of organic matter and nutrients stored in soils under contrasting management regimes. Canadian Journal of Soil Science Ottawa, 75, 529-538. https://doi.org/10.4141/cjss9 5-075

EMBRAPA (Empresa Brasileira de Pesquisa Agropecuária). (1997). Centro Nacional de Pesquisa de Solos: Manual de métodos de análise de solo (Vol. 2, p. 212).

EMBRAPA (Empresa Brasileira de Pesquisa Agropecuária). (2006). Sistema brasileiro de classificação de solos.

Endale, D. M., Schomberg, H. H., Jenkins, M. B., Franklin, D. H., \& Fisher, D. S. (2010). Management implications of conservation tillage and poultry litter use for Southern Piedmont USA cropping systems. Nutr Cycl Agroecosyst, 88, 299-313. https://doi.org/10.1007/s10705-009-9318-Z

Franchini, J. C., Crispino, C. C., Souza, R. A., Torres, E., \& Hungria, M. (2007). Microbiological parameters as indicators of soil quality under various soil management and crop rotation systems in southern Brazil. Soil and Tillage Research, 92, 18-29. https://doi.org/10.1016/j.still.2005.12.010

Ge, G., Li, Z., Fan, F., Chu, G., Hou, Z., \& Liang, Y. (2010). Soil biological activity and their seasonal variations in response to long-term application of organic and inorganic fertilizers. Plant Soil, 326, 31. https://doi.org/10.1007/s11104-009-0186-8

Howarth, W. (2007). Carbon cycling and formation of organic matter. In E. A. Paul (Ed.), Soilmicrobiology, ecology, and biochemistry (3rd ed., pp. 303-340). Academic Press, Amsterdam, The Netherlands. https://doi.org/10.1016/B978-0-08-047514-1.50016-0

Kominko, H., Gorazda, K., Wzorek, Z., \& Wojtas, K. (2017). Sustainable Management of Sewage Sludge for the Production of Organo-Mineral Fertilizers. Waste and Biomass Valorization, $1,10$. https://doi.org/10.1007/s12649-016-9805-9

Komiyama, T., Kobayashi, A. \& Yahagi, M. J. (2012). The chemical characteristics of ashes from cattle, swine and poultry manure. Journal of Material Cycles and Waste Management, 15, 106-110.

Li, L., Liang, X., Ye, Y., Zhao, Y., Zhang, V., Jin, V., ... Chen, Y. (2015). Effects of repeated swine manure applications on legacy phosphorus and phosphomonoesterase activities in a paddy soil. Biology and Fertility of Soils, 51, 167-181. https://doi.org/10.1007/s00374-014-0956-1

Mierzwa-Hersztek, M., Klimkowicz-Pawlas, A., \& Gondek, K. (2017). Influence of Poultry Litter and Poultry Litter Biochar on Soil Microbial Respiration and Nitrifying Bacteria Activity. Waste Biomass Valor, 1-11. https://doi.org/10.1007/s12649-017-0013-z

Mosaddeghi, M. R., Mahboub,i A. A., Zandsalimi, S., \& Unc, A. (2009). Influence of organic waste type and soil structure on the bacterial filtration rates in unsaturated intact soil columns. Jounal of Environmental Management, 90, 730-739. https://doi.org/10.1016/j.jenvman.2008.01.009

Nosrati, K. (2013). Assessing soil quality indicator under different land use and soil erosion using multivariate statistical techniques. Environ Monit Assess, 185(4), 2895-2907. https://doi.org/10.1007/s10661-0122758-y 
Novak, E., Carvalho, L. A., Santiago, E. F., \& Portilho, I. I. R. (2017). Chemical and microbiological attributes under different soil cover. Cerne, 23, 19-30. https://doi.org/10.1590/01047760201723012228

Oberholzer, H. R., Freiermuth Knuchel, R., Weisskopf, P., \& Gaillard, G. (2012). A novel method for soil quality in life cycle assessment using several soil indicators. Agronomy for Sustainable Development, 32, 639-649. https://doi.org/10.1007/s13593-011-0072-7

Oliveira, P. P. A., Boaretto, A. E., Trivelin, P. C. O., Oliveira, W. S., \& Corsi, M. (2003). Liming and fertilization for restoring degraded Brachiaria decumbens pasture on sandy soil. Scientia Agricola, 60, $125-131$. https://doi.org/10.1590/S0103-90162003000100019

Pare, G., Aubry, D., Lepanto, L., \& Sicotte, C. (2005). Evaluating PACS Success: A Multidimensional Model (pp. 147-155). $38^{\text {th }}$ Annual Hawaii International Conference on System Sciences (HICSS'05). https://doi.org/10.11 09/HICSS.2005.249

Pavinato, P. S., \& Rosolem, C. A. (2008). Disponibilidade de nutrientes no solo: decomposição e liberação de compostos orgânicos de resíduos vegetais. Revista Brasileira de Ciência do Solo, 32, 911-920. https://doi.org/10.1590/S0100-06832008000300001

Petrere, C., \& Anghinoni, I. (2001). Alteração de atributos químicos no perfil do solo pela calagem superficial em campo nativo. Revista Brasileira de Ciência do Solo, 25, 885-895. https://doi.org/10.1590/S0100-0683 2001000400011

Pinto, F. A., Santos, F. L, Terra, F. D., Ribeiro, D. O., Sousa, R. R. J., Souza, E. D., ... Paulino, H. B. (2012) Atributos de solo sob pastejo rotacionado em função da aplicação de cama de peru. Pesquisa Agropecuária Tropical, 42, 254-262. https://doi.org/10.1590/S1983-40632012000300002

Pulido, M., Schnabel, S., Contador, J. F. L., Lozano-Parra, J., \& Gómez-Gutiérrez, A. (2017). Selecting indicators for assessing soil quality and degradation in rangelands of Extremadura (SW Spain). Ecological Indicators, 74, 49-61. https://doi.org/10.1016/j.ecolind.2016.11.016

Quadro, M. S., Castilhos, D. D., Castilhos, R. M. V., \& Vivian, G. (2011). Biomassa e atividade microbiana em solo acrescido de dejeto suíno. Revista Brasileira Agrociência, 17, 85-93.

Sá, J. C. M., Seguy, L., Tivet, F., Lal, R., Bouzinac, S., Borszowskei, P. R., ... Friedrich, T. (2013). Carbon depletionby ploughing and its restoration by no-till cropping systems in OXISOLS of sub-tropical and tropical agro-ecoregions in BRAZIL. Land Degradation \& Development, 24,115.

Sepat, S., Behera, U. K., Sharma, A. R., Das, T. K., \& Bhattacharyya, R. (2014). Productivity, Organic Carbon and Residual Soil Fertility of Pigeonpea-Wheat Cropping System under Varying Tillage and Residue Management. Proceedings of the National Academy of Sciences, India Section B: Biological Sciences, 84, 561-571. https://doi.org/10.1007/s40011-014-0359-y

Silva, I. F., \& Mielniczuk, J. (1997). Avaliação do estado de agregação do solo afetado pelo uso agrícola. Revista Brasileira de Ciência do Solo, 21, 313-319.

Silva, I. R. S., \& Mendonça, E. D. (2007). Matéria Orgânica do Solo. In R. F. Novais, V. H. Alvarez, N. F. Barros, R. L. F. Fontes, R. B. Cantarutti, \& J. C. L. Neves (Eds.), Fertilidade do solo (Vol. 6, pp. 276-357).

Souza, E. D., Costa, S. E. V. G. A., Anghinoni, I., Carvalho, P. C. F., Andrigueti, M., \& Cao, E. (2009). Estoques de carbono orgânico e de nitrogênio no solo em sistema de integração lavoura-pecuária em plantio direto, submetido a intensidades de pastejo. Revista Brasileira de Ciência do Solo, 33, 829-1836. https://doi.org/ 10.1590/S0100-06832009000600031

Sparling, G. P., \& West, A. W. (1988). A direct extraction method to estimate soil microbial C: Calibration in situ using microbial respiration and ${ }^{14} \mathrm{C}$ labeled sells. Soil Biology and Biochemistry, 20, $337-343$. https://doi.org/10.1016/0038-0717(88)90014-4

Stewart, C. E., Paustian, K., \& Conant, R. T. (2007). Soil carbon saturation: Concept, evidence and evaluation. Biogeochemistry, 86, 19. https://doi.org/10.1007/s10533-007-9140-0

Tedesco, M. J., Volkweiss S. J., \& Bohnen, H. (1995). Análise de solo, plantas e outros materiais. Porto Alegre: Faculdade de Agronomia/Universidade Federal do Rio Grande do Sul. https://doi.org/10.1007/978-94-0178807-6_17

Tewolde, H., \& Sistani, K. R. (2014). Cotton Production Improvement and Environmental Concerns from Poultry Litter Application in Southern and Southeastern USA Soils. In Z. He, \& H. Zhang (Eds.), Applied Manure and Nutrient Chemistry for Sustainable Agriculture and Environment. Springer, Dordrecht. 
Tomlinson, P. J., Saving, M. C., \& Moore, P. A. (2015). Long-term applications of untreated and alum-treated poultry litter drive soil nitrogen concentrations and associated microbial community dynamics. Biology and Fertility of Soils, 51, 43-55. https://doi.org/10.1007/s00374-014-0949-0

Vance, E. D., Brookes, P. C., \& Jenkinson, D. S. (1987). An extraction method for measuring soil microbial biomass. Soil Biology and Biochemistry, 19, 703-707. https://doi.org/10.1016/0038-0717(87)90052-6

Veum, K. S., Goyne, K. W., Kremer, R. J., Miles, R. J., \& Sudduth, K. A. (2014). Biological indicators of soil quality and soil organic matter characteristics in an agricultural management continuum. Biogeochemistry, 117(1), 81-99.

Zang, H., Blagodatskaya, E., Wang, J., Xu, X. L., \& Kuzyakov, Y. (2017). Nitrogen fertilization increases rhizodeposit incorporation into microbial biomass and reduces soil organic matter losses. Biol Fertil Soils, 53, 419. https://doi.org/10.1007/s00374-017-1194-0

Zuber, S. M., Behnke, G.D., Nafziger, E. D., \& Villamil, M. B. (2017). Multivariate assessment of soil quality indicators for crop rotation and tillage in Illinois. Soil and Tillage Research, 174, 147-155. https://doi.org/ 10.1016/j.still.2017.07.007

\section{Copyrights}

Copyright for this article is retained by the author(s), with first publication rights granted to the journal.

This is an open-access article distributed under the terms and conditions of the Creative Commons Attribution license (http://creativecommons.org/licenses/by/4.0/). 